\title{
PENGEMBANGAN APLIKASI E-VOTTING UNTUK PEMILIHAN KETUA OSIS BERBASIS ANDROID (STUDI KASUS: SMKN 1 KRAGILAN, KECAMATAN KRAGILAN, KABUPATEN. SERANG PROVINSI BANTEN)
}

\author{
Rodianto $^{1^{*}, \text { Jannatun Aliyah }}{ }^{2}$, Irsyad M.D ${ }^{3}$ \\ ${ }^{1,2}$ Teknik informatika, Universitas Teknologi Sumbawa \\ email: rodianto.mursali@gmail.com*
}

\begin{abstract}
Abstrak: Penelitian ini bertujuan untuk mengembangkan aplikasi $e$-votting untuk pemilihan ketua osis berbasis android, di smkn 1 kragilan agar pemilihan ketua osis dapat berjalan dan tidak mengganggu pelajaran nantinya. Dengan adanya aplikasi $e$-votting ini dapat memudahkan para siswa. Votting sendiri dikenal dengan istilah electronicvotting atau lazim disebut dengan $e$-votting, metode penelitian yang digunakan dalam penelitian ini adalah pengembangan sistem, yaitu experimen untuk merancang bangun aplikasi $e$-votting dengan android studio. Aplikasi $e$-votting dikembangkan menggunakan berbasis android. Aplikasi $e$-votting dibangun dengan menggunakan java, sistem $e$-votting ini tidak terlepas dari kekurangan, diantaranya perubahan beberapa menu untuk mencegah cybercrime. Untuk pengembangan perangkat lunaknya penulis menggunakan model waterfal.
\end{abstract}

Kata Kunci : Aplikasi, Smkn 1 Kragilan, Sistem, E-Votting

\begin{abstract}
The research is aimed at deleloping the e-votting application for the android based class president, in smkn 1 kragilan so that the presidential election can countinue and not interfere with the lesson. With the e-votting application, it can make it easier for students. Votting itself may be either electronic votting or generally called e-votting. The research method used in this study is the delelopment of systems, it's an experiment to design the e-votting application with the android studio. E-Votting application deleloped using java, the e-votting system doesn't break from deprivation, among them are several menus to prevent the cyber crime. For sofware development writers use waterfal medels.
\end{abstract}

Keywords : Applicatoin, Smkn 1 Kragilan, System, E-Votting

\section{PENDAHULUAN}

Di era globalisasi sekarang ini, teknologi sudah berkembang semakin pesat. Kebutuhan manusia akan teknologi pun kian meningkat, banyak orang mulai dari anak-anak hingga orang dewasa ikut ambil bagian dalam penggunaan teknologi dimasa sekarang ini. Pihak perkantoran pun juga tidak mau kalah dalam hal pemanfaatan teknologi. Telah banyak aplikasi-aplikasi yang dibuat untuk membantu menunjang kinerja dari para pekerja dikantor guna memaksimalkan daya produksi mereka. Namun tentu saja bukan hanya kalangan perkantoran saja yang bisa menggunakan kemudahan yang di tawarkan oleh teknologi, lembaga pendidikan mulai dari tingkat terendah sampai tingkat tertinggi seperti universitas pun sudah mampu menggunakannya, bahkan mengembangkan serta menciptakan yang baru.

Votting merupakan sebuah metode yang digunakan untuk pengambilan keputusan. Kegiatan votting dilakukan untuk menghimpun aspirasi dengan tujuan menentukan jalan keluar yang dianggap paling baik dalam menyelesaikan permasalahan.Kegiatan votting yang secara luas dikenal oleh masyarakat adalah pemilu atau pilkada yang diselenggarakan oleh KPU votting juga biasa di gunakan di dunia pendidikan.
SMKN 1 Kragilan tempat semua siswa/i menimba ilmu dan dimana di SMKN 1 Kragilan ini setiap tahunnya selalu mengadakan pemilihan osis, pemilihan osis sendiri di jalankan menggukan web sehingga setiap tahun harus menggunakan laboratorium komputer dari TKJ ( Teknik Komputer Jaringan ) yang di mana komputer nya banyak yang rusak dan harus diperbaiki. Sehingga persiapan untuk melakukan pemilihan ketua osis harus lama dan membutuhan tenaga kerja yang banyak karna banyak komputer yang tidak layak pakai, jaringan di SMKN 1 Kragilan pun sangat lambat sehingga menghambat proses pemilihan itu sendiri, yang dimana pemilihannya harus menggunakan jaringan yang stabil dan komputer yang layak agar tidak mengganggu saat pemilihan nantinya. Pada pemilihan ketua osis sebelumnya terdapat beberapa kendala yaitu : (1) komputer yang di gunakan pada saat pemilihan tidak layak digunakan karena banyak perangkat komputer yang tidak layak, (2) jaringan yang digunakan sangat lambat sehingga menghambat pemilihan dan memerlukan waktu yang lama untuk pemilihan dengan banyaknya siswa tersebut, (3) mengganggu proses pembelajaran siswa.

Berdasarkan permasalahan di atas peneliti membuat pengembangan aplikasi $e$-votting untuk 
pemilihan ketua osis berbasis android diharapkan mampu memberikan solusi terhadap permasalahan yang di hadapi SMKN 1 Kragilan. Dimana aplikasi yang di buat sangat mudah digunakan nantinya oleh SMKN 1 Kragilan tanpa menggukan jaringan dan komputer sekolah.

\section{TINJAUAN PUSTAKA}

Setelah peneliti melakukan telaah terhadap beberapa penelitian terkait $\boldsymbol{e}$-votting untuk pemilihan ketua osis, ada beberapa yang memiliki keterkaitan dengan penelitian yang peneliti lakuakan.

Penelitian pertama yang berhasil peneliti temukan adalah peneliti yang dilakukan Ryadi putra (2018) yang berjudul "Aplikasi votting pemilihan ketua organisasi siswa intra sekolah (osis) pada MA Nurul Ihsan NW Tilawah berbasis web".Tujuan penelitian ini untuk merancang dan membangun aplikasi e-voting pemilihan ketua osis guna mempermudah dalam memilih ketua osis priode selanjut nya. Setelah melihat hasil penelitian yang di lakukan ryadi putra (2018) dapat ditarik kesimpulan bahwa aplikasi yang dirancang dan di bangun hanya mengenalkan tampilan pada web nya saja, sehingga saat terjadi kendala error pada web siswa tidak dapat mengakses nya lagi.

Penelitian kedua yang berhasil peneliti temukan adalah penelitian yang dilakukan Linda yeti (2017) yang berjudul "sistem informasi pemilihan calon ketua osis di SMA Pawyatan Daha" tujuan penelitian merancang dan membangun system informasi pemilihan calon ketua osis guna mempermudah mencari informasi bakal calon ketua osis priode selanjutnya. Setelah melihat hasil penelitian yang di lakukan linda yeti (2017) dapat ditarik kesimpulan hanya menyediakan system informasinya saja.

Pada penelitian pertama aplikasi votting berbasis web yang digunakan memiliki kekurangan pada tampilan web dimana hanya dapat menampilkan pemilihan tetapi tidak dapat menampilkan hasil dari pemilihannya sehingga harus dilakukan perhitungan secara manual. Pada penelitian kedua aplikasi web yang dibuat hanya sebagai media informasi dari calon ketua dan wakil yang mendaftar, tidak dapat melakukan votting pada aplikasi web tersebut

Dari hasil kedua penelitian tersebut dapat di simpulkan bahwa kedua nya masih memiliki kekurangan baik dari segi aplikasi dan teknologi yang di pilih serta fitur dan desain yang masih kurang dimata pengguna, dengan demikian penelitian mencoba mengembangkan aplikasi pemilihan ketua osis menggunakan $e$-votting berbasis android agar pengguna merasa puas baik dari segi fiture dan desain dari teknologi yang digunakan.

\section{DASAR TEORI}

Adapun dasar teori yang mendukung dalam pembuatan laporan ini, sebagai berikut

\section{Pengembangan}

Menurut sugiono 2017, pengembangan merupakan proses atau metode yang digunakan untuk mengembangkan produk. Mengembangkan produk dalam arti yang dapat berupa pembaruan produk yang telah ada sehingga menjadi lebih praktis, efektif, dan efesien ataupun menciptakan produk baru yang sebelumnya belum pernah ada.

\section{E-Votting}

Menurut Pratchett dan wingflid (2002), terdapat beberapa pelajaran dari beberapa percobaan di inggris, yaitu:

a. Keamanan dan intergritas pilihan tidak terlalu di uji dalam percobaan. Hal ini dikarnakan tidak ada hal yang berkaitan dengan masalah keamanan yang di ujikan selama percobaan di samping itu, dari segi cangkupan, pengujian keamanan tidak dapat di akui akurasinya jika hanya di lakukan dalam lingkup percobaan di sejumlah wilayah seperti dilakukan pada bulan mei pada tahun 2002. Pengujian terhadap keamanan dan intergritas pilihan hanya dapat datang ketika pemilu tingkat nasional atau referendum secara luas menggunakan e-votting.

b. Masalah kerahasian dan privaty juga tidak mendapat tempat penting dari percobaan tersebut.

c. Masalah penetralisasi dan akses teknologi hanya di alamatkan oleh percobaan.

Yang menarik adalah bahwa di samping terdapat pengembangan secara teknis, terdapat juga pengembangan secara hukum. Pengembangan dari sisi hukum dilakukan dengan mengamandemen legalisasi yang sudah ada. Hasil dari amandemen legalisasi itu adalah di keluarkan nya The Reprensentation Of The People Act 2002 pada tanggal 18 juli 2002. Secara garis besar dikeluarkan produk hukum itu ditunjukan untuk makin memperluas kemungkinan pelaksaana $e$-votting di banyak pemerintahan local inggris.

\section{Metode pengembangan prangkat lunak waterfall}

Waterfall adalah metode klasik yang sistematis dalam membangun sebuah perangkat 
lunak. Metode ini tergolong ke dalam model generik pada rekayasa perangkat lunak. Pendekatan yang dilakukan sistemais dan berurutan menjadi alasan mengapa metode ini disebut waterfall.

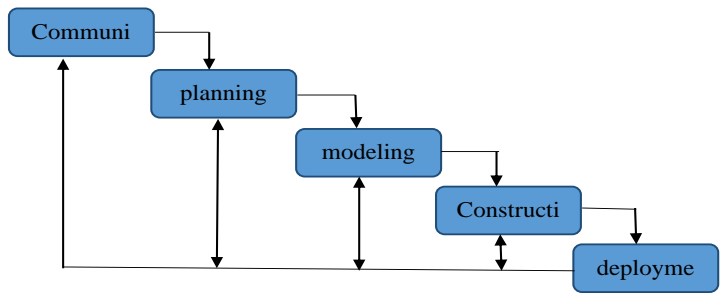

Gambar 1 metode waterfall

Adapun fase-fase dalam meode Waterfall menurut Pressman:

\section{a. Communication}

Memahami permasalahan dan kebutuhan customer guna mendefinisikan tujuan yang ingin dicapai adalah hal yang wajib dilakukan sebelum mulai mengerjakan hal yang bersifat teknis. Dalam tahapan ini dilakukan inisisalisasi proyek seperti menganalisis permasalahan yang sedang dialami oleh customer dan mengumpulkan data-data yang diperlukan, serta mendefinisikan software yang akan dibangun.

b. Planning

Tahap planing atau perencanaan akan menjelaskan estimasi dan tugas-tugas teknis yang akan dilakukan, risiko, sumber daya yang dibutuhkan, produk yang ingin dihasilkan, penjadwalam kerja dan tracking proses pengerjaan sistem.

\section{c. Modeling}

Pada tahapan ini dilakukan perancangan serta pemodelan arsitektur dari sistem software yang akan dibangun. Kegiatan ini berfokus pada perancangan struktur data, arsitektur software, interface dan algoritma program. Tujuan dari kegiatan tersebut adalah untuk memahami gambaran dari apa yang akan dikerjakan.

d. Construction

Pada tahapan ini dilakukan proses penerjemahan hasil analisis dan desain ke dalam bentuk kode program. Kegiatan ini lebih dikenal dengan istilah pengkodean atau programing. Setelah proses pengkodean selesai, sistem atau software tersebut harus melewati tahapan pengujian untuk memastikan apakah hasil implementasi telah sesuai dengan rancangan.

e. Deployment
Tahapan deployment merupakan tahapan implementasi software ke customer, pemeliharaan software secara berkala, evaluasi software dan pengembangan software berdasarkan permintaan customer supaya sistem dapat tetap berjalan dan berkembang.

Metode waterfall adalah pendekatan yang cocok diterapkan pada proyek pembuatan sistem baru dan juga pengembangan software dengan tingkat resiko yang relatif kecil. Keuntungan menggunakan metode waterfall antara lain proses pengerjaan yang lebih terstruktur sehingga akan menghasilkan software dengan kualitas yang baik dan tetap terjaga. Dari sisi user dapat menguntungkan, karena dapat merencanakan dan menyiapkan kebutuhan data dan proses yang diperlukan sejak awal.

\section{METODE PENELITIAN}

Pada penelitian ini penulis menggunakan metode penelitian kualitatif yang bersifat deskriptif. Dalam metode ini, yang dilakukan penulis adalah mengumpulkan dan menganalisis data yang hanya berupa kata-kata (lisan maupun tulisan). Dalam hal ini penulis membuat pengembangan aplikasi $e$ votting untuk pemilihan ketua osis berbasis android untuk membantu proses pemilihan pada SMKN 1 Kragilan. Metode pengembangan dalam perancangan penelitian ini adalah metode pengembangan perangkat lunak waterfall.

Adapun tahapan yang dilakukan dalam melakukan penelitian ini adalah sebagai berikut:

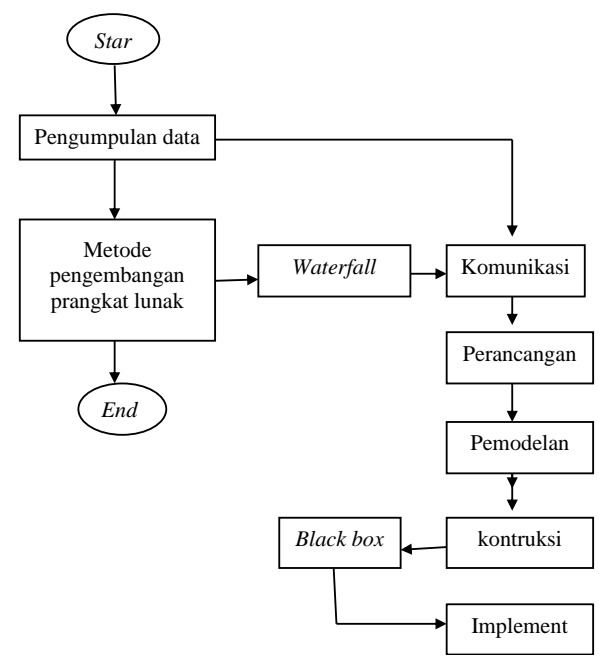

Gambar 2 Alur penelitian

Pada saat melakukan penelitian, penulis mengidentifikasi keadaan yang akan diteliti terlebih dahulu. Setelah mendapat berbagai data yang diperlukan,. kemudian penulis mulai membuat aplikasi dengan menggunakan metode pengembangan waterfall. Setelah tahap pembuatan 
aplikasi selesai, maka dilakukan tahap uji coba terhadap aplikasi. Apabila sukses, aplikasi akan dilakukan tahap implementasi dan selesai. Akan tetapi, apabila pada saat uji coba aplikasi gagal, maka akan dilakukan perancangan ulang pada aplikasi.

\section{Analisi perancangan sistem}

Berikut ini merupakan rancangan pengembangan aplikasi e-votting untuk pemilihan ketua osis berbasis android

\subsection{Use case diagram}

Berikut ini merupakan use case diagram dari proses pemilihan pada Aplikasi $e$-voting Untuk Pemilihan Ketua Osis Berbasis Android.

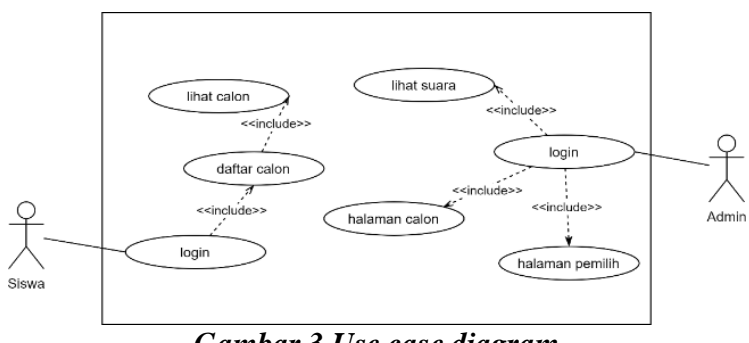

Gambar 3 Use case diagram

\subsection{Aktivity diagram}

Activity diagram menggambarkan serangkaian alur proses dari setiap fungsi yang tedapat didalam aplikasi. Activity diagram pada aplikasi e-votting Untuk Pemilihan Ketua Osis Berbasis Android dibagi menjadi beberapa bagian antara lain:

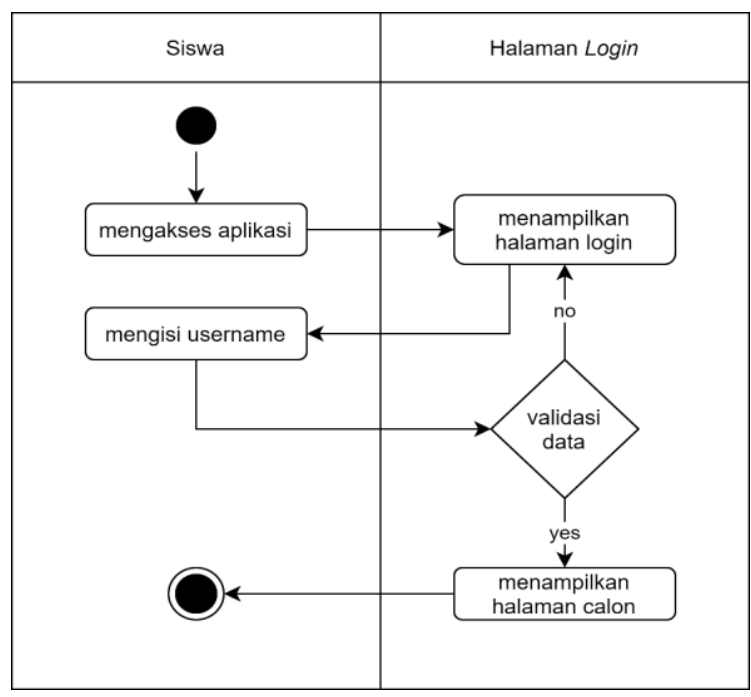

Gambar 4 Aktivty diagram login

Dari gambar di atas dapat dilihat bahwa saat siswa mengakses aplikasi maka akan tampil halaman login dan dapat mengisi username untuk masuk, username yang digunakan telah didaftarkan oleh admin.

\subsection{Sequence diagram}

Sequence diagram menggambarkan hubungan objek yang berdasarkan urutan waktu yang terdapat didalam aplikasi. Adapun sequence diagram pada aplikasi ini antara lain:

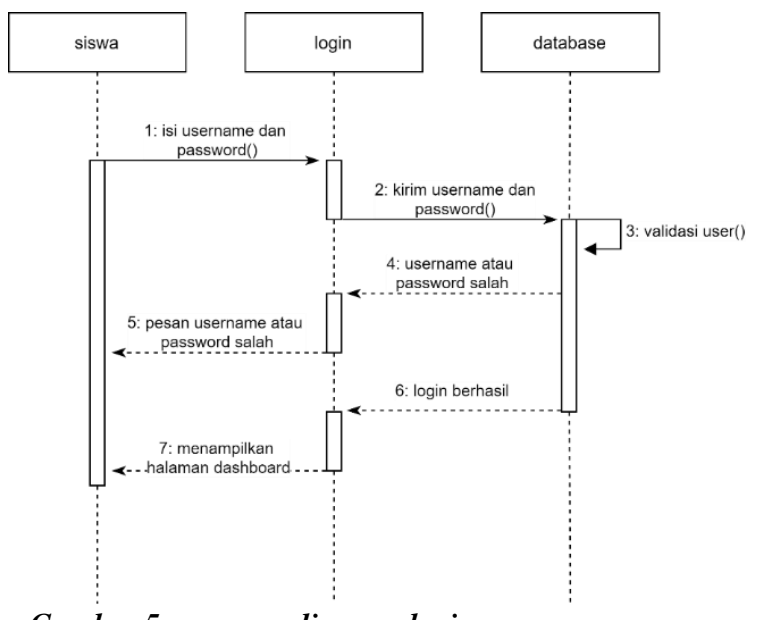

Gambar 5 sequence diagram login

Pada rancangan sequence diagram di atas menjelaskan alur saat siswa melakukan login, proses dimulai dari siswa mengakses aplikasi kemudian masuk ke halaman login dan mengisi data username, setelah itu aplikasi akan memverifikasi apakah data terdaftar atau tidak. Apabila terdaftar maka akan masuk ke halaman daftar calon, apabila tidak maka akan menampilkan pesan gagal login.

\subsection{Class diagram}

Class diagram merupakan hubungan antar kelas dan alur jalannya activity main. java pada sebuah sistem. Berikut ini adalah class diagram pada aplikasi e-votting untuk pemilihan ketua osis berbasis android.
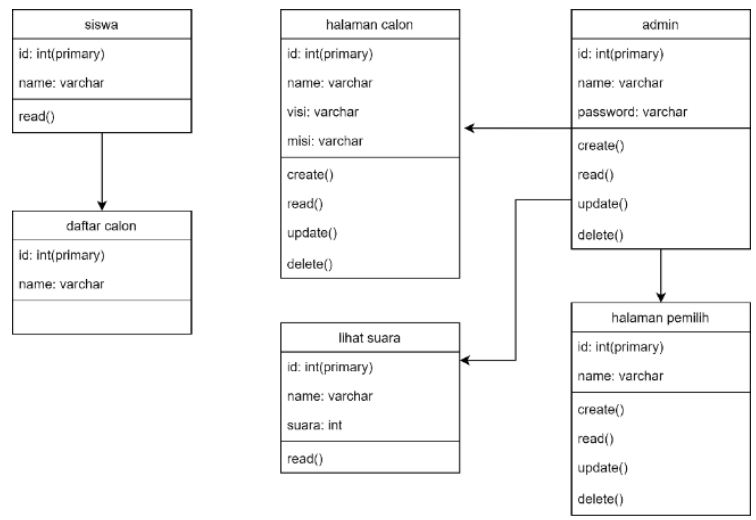

Gambar 6 Class diagram

\section{HASIL DAN PEMBAHASAN}

\section{Imprementasi program}

Implementasi program pada Aplikasi EVoting untuk pemilihan ketua osis Berbasis Android adalah sebagai berikut: 
a. Tampilan icon pada aplikasi

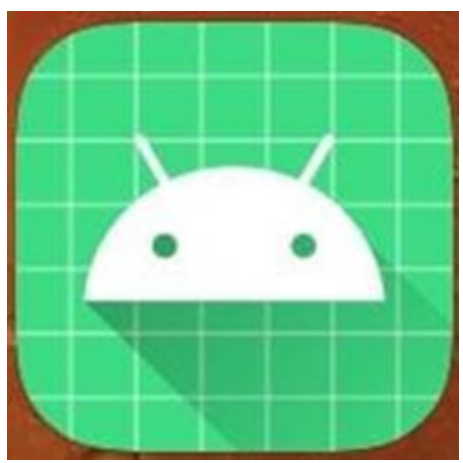

Gambar 7 icon aplikasi

Gambar diatas merupakan tampilan icon aplikasi yang digunakan pada aplikasi E-Votting untuk pemilihan ketua osis berbasis android.

\section{b. Tampilan spashscreen pada aplikasi}
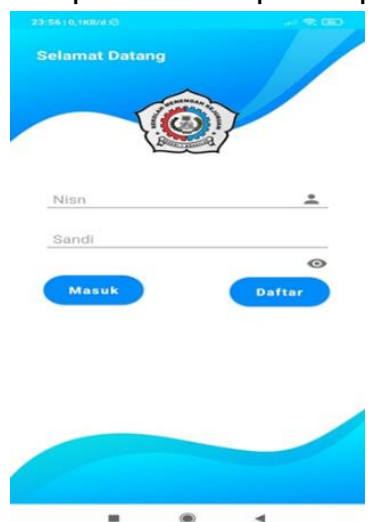

Gambar 8 Spashscreen aplikasi

Gambar diatas merupakan tampilan awal saat pertama kali user membuka aplikasi.;

\section{c. Tampilan menu daftar}

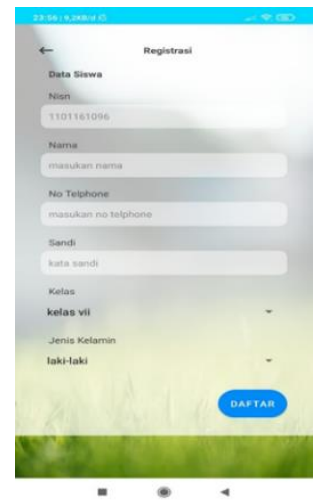

Gambar 9 menu daftar aplikasi

Pada menu daftar siswa diharuskan daftar terlebih dahulu agar bisa liat calon ketua osis yang sudah terdaftar. Dan siswa yang sudah daftar harus di validasi dulu oleh admin agar bisa memilih calon ketua osis di aplikasi.

\section{d. Tampilan dasboard aplikasi}

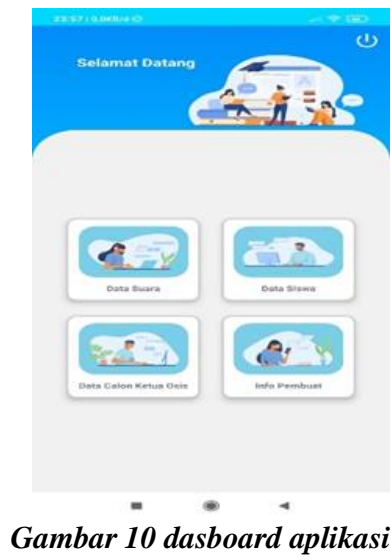

Pada menu utama/dashboard terdapat 4 menu utama diantaranya menu data suara, menu data siswa, menu data calon ketua osis, dan menu info pembuat. Setiap menu yang terdapat dalam menu utama aplikasi memiliki fiture yang sama seperti menu data suara, menu data siswa, menu data calon ketua osis, dan menu info pembuat yang dimana di dalamnya sama-sama menampilkan detail informasi.

\section{e. Tampilan data suara}

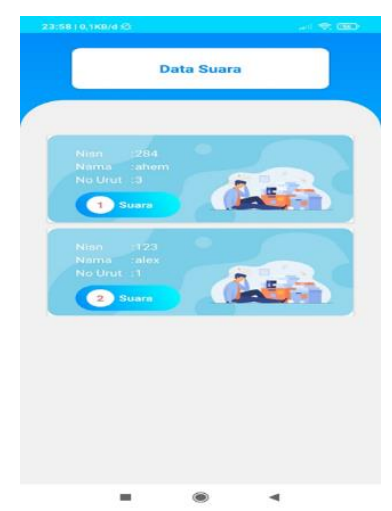

Gambar 11 data suara aplikasi

Pada tampilan menu data suara, user dapat melihat detail informasi yang ditampilkan aplikasi yaitu informasi berapa suara yang sudah memilih pada calon ketua osis. 


\section{f. Tampilan menu data siswa}

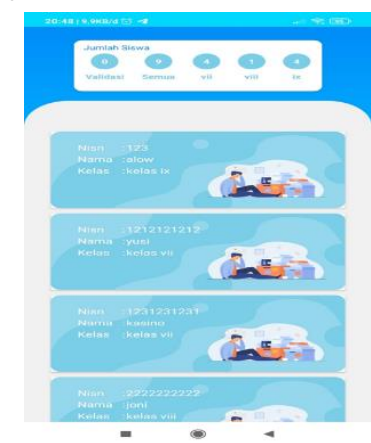

Gambar 12 data siswa aplikasi

Pada tampilan menu data siswa, user dapat melihat detail informasi yang ditampilkan aplikasi yaitu informasi berapa siswa yang sudah tervalidasi dari semua kelas.

\section{g. Tampilan menu data calon ketua osis}

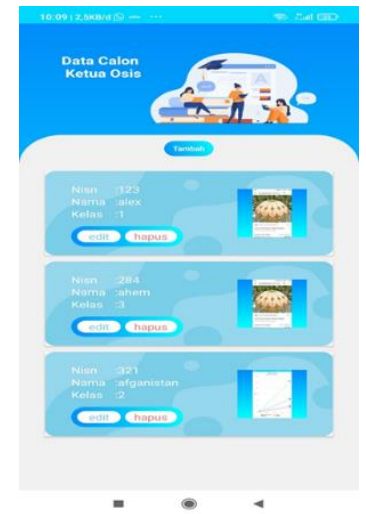

Gambar 13 data calon ketua osis

Pada tampilan menu data calon ketua osis, user dapat melihat detail informasi yang di tampilkan aplikasi yaitu mencoblos calon ketua osis atau liat detail visi misi yang calon ketua osis berikan.

\section{h. Tampilan menu info pembuat}

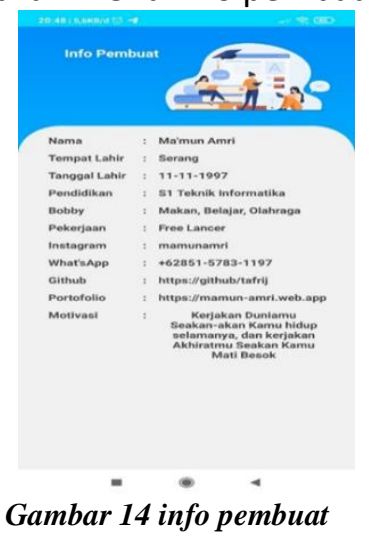

Pada tampilan menu data info pembuat, user dapat melihat detail informasi yang di tampilkan aplikasi yaitu informasi si pembuat aplikasi $e$-votting untuk pemilihan ketua osis berbasis android.

i. Tampilan menu pemilih

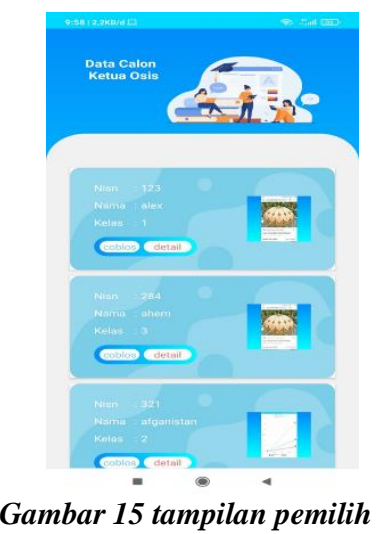

Pada tampilan menu data pemilih, user dapat memilih ingin mencoblos ketua osis atau melihat detail visi misi yang ditampilkan aplikasi sipembuat aplikasi e-votting untuk pemilihan ketua osis berbasis android.

\section{KESIMPULAN DAN SARAN}

\section{Kesimpulan}

Berdasarkan penjelasan dalam penelitian ini kesimpulan yang dapat diambil yaitu Aplikasi EVotting untuk pemilihan ketua osis Berbasis Android Menggunakan bahasa pemrograman java dengan IDE android studio 4.2. Sedangkan belum di uji coba ke siswa terkendala sekolah yang libur. Dengan terselesaikan nya aplikasi ini dapat membantu untuk lebih mudah dalam memilih calon ketua osis.

\section{Saran}

Berdasarkan kesimpulan yang sudah di uraikan diatas, diperlukan adanya pengembangan agar aplikasi ini dapat bermanfaat untuk kedepannya yaitu dapat menambahkan fitur-fitur pada data suara, data siswa, data calon ketua osis , dan data info pembuat. Agar menjadi grafik yang lebih baik kedepan nya.

\section{DAFTAR PUSTAKA}

(1) Nugroho, A, W. 2014. Perancangan EVoting Berbasis Web Studi Kasus Pemilihan Kepala Daerah Sukoharjo. http://digilib.uinsuka.ac.id/6324/, diakses pada tanggal : 10 Agustus 2015.

(2) Muhammad Guntur "Perancangan Sistem EVoting Pemilihan Kepala Desa Pada Kecamatan Teupah Selatan Kabupaten Simeulue"Vol. 2 No. 2 Agustus 2020.

(3) Rizki Amelia "Perancangan Aplikasi E-Vote Berbasis Mobile Android Pada Pemilihan Ketua 
Rt Ngestiharjo Rt 02/15 Siswodipuran Boyolali'Vol.2, No.3, November 2018.

(4) Kusnita Yusmiarti "E-Voting Pemilihan Kepala Desa Berbasis Android"Vo. 8 No. 2 Februari 2020

(5) Raditya Prananda "Rancang Bangun Aplikasi EVoting Berbasis Android"Vol. 5, No. 1, (2017)

(6) Fajarianto, "Prototype Pelayanan Akademik Terhadap Komplain Mahasiswa Berbasis Mobile," J. Lentera Ict, vol. 3, no. 1, pp. 54-60, 2016.

(7) M. S. Mustaqbal, R. F. Firdaus, H. Rahmadi, "Pengujian Aplikasi Menggunakan Black Box Testing Boundary Value Analysis (Studi Kasus : Aplikasi Prediksi Kelulusan SNMPTN)," vol. I, no. 3, pp. 31-36, 2015.

(8) Y. Yudhanto, A. Wijayanto, Mudah Membuat dan Berbisnis Aplikasi Android dengan Android Studio. Jakarta: PT Elex Media Komputindo, 2017.

(9) S. P. Roger, Rekayasa Perangkat Lunak (Pendekataan Praktisi), 7th ed. Yogyakarta, 2010.

(10) De Vuyst, B., \& Fairchild, A. (2005). Experimenting with Electronic Voting Registration: the Case of Belgium. The Electronic Journal of e-Government.

(11) Safaat, N. 2014. Android Pemrogaman Aplikasi Mobile Smarthphone dan tablet PC berbasis Android. Bandung : Informatika. 